\title{
PREPARATION OF TEACHERS OF TECHNICAL SUBJECTS IN THE OPINION OF TEACHERS AND STUDENTS
}

\author{
Danka LUKÁČOV $\boldsymbol{A}^{*}$, Univerzita Konštantína Filozofa v Nitre \\ Gabriel BÁNESZ, Univerzita Konštantína Filozofa v Nitre
}

Přijato: 25. 11. 2015 / Akceptováno: 17. 12. 2015

Typ článku: Výskumný článok

DOI: $10.5507 /$ jtie.2016.002

Abstract: Improving the quality of education at universities is possible only if we know the educational content of the courses that we confront with the real use of graduate in employment practice. It is then possible to plan changes in curricula, in the organization of studies and to manage the university equipment of teaching aids. After the changes in the curricula of study programs is necessary to ascertain whether managed to live up to expectations on the part of teachers as well as students. Our suggested changes to the content of the courses as well as the organization of teaching was positively evaluated by the students and teachers who teach in the study programs.

Key words: labor market, graduate, requirements, questionnaire.

\section{PRÍPRAVA UČITELOV TECHNICKÝCH PREDMETOV V NÁZOROCH PEDAGÓGOV A ŠTUDENTOV}

Resumé: Zvyšovanie kvality vzdelávania na univerzitách je možné len vtedy, ak poznáme edukačné obsahy študijných programov, ktoré konfrontujeme $s$ reálnym uplatnením absolventov $v$ praxi. Potom je možné plánovat' zmeny $v$ študijných plánoch, organizácii štúdia a vo vybaveni univerzity potrebnými učebnými pomôckami. Po uskutočnení zmeny v študijných plánoch študijných programov je potrebné zistit', či sa podarilo naplnit' očakávania zo strany vyučujúcich, ale aj študentov. Nami navrhnuté zmeny vobsahu študijných programov ako aj vorganizácii výučby boli pozitivne hodnotené študentmi ajpedagógmi, ktori v študijných programoch vyučujú, čo dokazuje náš prieskum.

Kl'účové slova: trh práce, absolvent, požiadavky, dotazník.

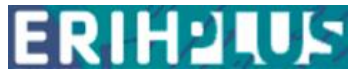

*Autor pro korespondenci: dlukacova@ukf.sk
This journal was approved on 2015-04-23 according to ERIH PLUS criteria for inclusion. 


\section{1 Úvod}

Správanie vysokých škôl je založené na špecifickej štruktúre interakcií medzi trhom práce a absolventmi vysokých škôl, ktorá závisí od úrovne vytvoreného l'udského kapitálu. V súlade $\mathrm{s}$ tým, vysokoškolské vzdelávanie ako faktor zlepšenia kvality l'udského kapitálu poskytuje prístup k vstupu absolventov na trh práce. Dostupnost' získania vysoko kvalitného l'udského kapitálu je stimulom pre študentov získat' vyššie vzdelanie. (Chaschin, 2014)

Rozhodujúcim faktorom podmieňujúcim vstup úspešného absolventa školy na trh práce je samotný systém školského vzdelávania - jeho organizácia, podiel všeobecného a odborného kurikula v rámci školského vzdelávania, spôsob tvorby školských kurikúl, ich obsah a schopnost' reagovat' na meniace sa požiadavky praxe, interakcia medzi zamestnávatel'skou sférou a vzdelávacím systémom. (Inštitút pre výskum práce a rodiny, 2010) Pracovníci inštitúcí, ktorí sa zaoberajú tvorbou obsahov pre jednotlivé stupne vzdelávania, sa opierajú o zistenia vedných odborov, zahraničné skúsenosti, ale málokedy alebo vôbec nie o výsledky skúmania postojov a názorov absolventa daného stupňa školy. (Rybalko, Epelboim, 2014)

$\mathrm{Na}$ Pedagogickej fakulte Univerzity Konštantína Filozofa v Nitre sa pripravujú do praxe učitelia pre základné školy. Jedným zo študijných odborov je Učitel'stvo predmetu technika. V súvislosti so zmenami v kurikule predmetu technika na základnej škole, ktoré predpokladajú u učitel'ov nové vedomosti a zručnosti, uskutočnili sme inováciu študijného programu zameranú najmä na inováciu odborno - predmetových kompetencií učitel’ov (Bajtoš, Šnajder, Orosová, Kireš, 2009) a realizovanú v týchto aktivitách:

- zlepšenie materiálno - technického zabezpečenia študijných programov prostredníctvom moderných učebných pomôcok,

- analýza štruktúry a obsahu študijných programov pre učitel'stvo predmetu technika (bakalársky aj magisterský stupeň),

- analýza informačných listov študijných predmetov,

- konzultácie študijných programov a predmetov so zástupcami firiem, inštitúcií ako aj odborníkov z praxe.

Všetky získané informácie sme zapracovali do návrhu nových študijných plánov a informačných listov. Zároveň prebiehalo obstarávanie učebných pomôcok, ktoré sa podarilo $\mathrm{v}$ priebehu roka 2014 získat', vyškolit' sa na prácu s nimi a začat' na nich pilotnú výučbu. Učebnými pomôckami boli vybavené dve učebne, z ktorých tak vznikli špecializované pracovisko na softvérové technológie a odborná učebňa pre výučbu programovania PLC.

\section{Materiálno-technické zabezpečenie pre inováciu študijných programov}

V rámci inovácie študijných programov sme inovovali študijné predmety tak, aby lepšie reflektovali potreby trhu práce. Tieto predmety predpokladajú vytváranie praktických zručností u študentov, ktoré možno nadobudnút iba nácvikom za použitia reálnych alebo virtuálnych zariadení. V rámci inovácie študijného programu učitel'stvo predmetu technika boli preto zabezpečené nasledovné učebné pomôcky: 
- z moderných technológií, ako sú CNC systémy, priemyselné automaty, robotické systémy a pod. katedra získala súpravu $\mathrm{CNC}$ programovania $3 \mathrm{D}$, súpravu $\mathrm{CNC}$ programovania (e-learningový program) a súpravu programovania WIN NC,

- v strojárskych technológiách katedra získala súpravu pre výučbu pneumatiky a súpravu pre výučbu elektropneumatiky, výukový program pre oblast' skúšky tvrdosti materiálov, výukový program pre oblast' deštrukčných skúšok materiálov a výukový program pre tepelné spracovanie ocele.

- v grafickej komunikácii katedra získala CAD/CAM systém ALPHA CAM a jeho nadstavbu CAM.

- v aplikácii bezpečnosti do priemyselnej praxe katedra získala pracovisko pre výučbu základných bezpečnostných a signalizačných obvodov a revízny kufrík obsahujúci súpravu meracích prístrojov na meranie prechodového odporu, impedancie slučky, skratového prúdu a izolačného odporu.

Všetky uvedené učebné pomôcky boli zaradené do vzdelávacieho procesu v predmetoch: Grafická komunikácia v technike, Časti strojov a stroje, Stroje a mechanizmy, CNC systémy, Materiály a technológie, Pohony strojov, Elektrické signalizačné, istiace a bezpečnostné systémy.

$\mathrm{K}$ dodaným učebným pomôckam vypracovali pedagógovia e-learningové kurzy v systéme Moodle. Tieto kurzy boli vytvorené pre dané učebné pomôcky tak, aby sa študenti mohli pripravovat' na prácu s pomôckami na praktických cvičeniach. Išlo o nasledovné kurzy: Stroje, mechanizmy a časti strojov, Aplikovaná matematika a fyzika, Elektrotechnológia, Materiály a technológia, Aplikácia informačných a komunikačných technológií, Grafická komunikácia v technike I, Počítačová grafika.

\section{Ciel' prieskumu a použité metódy}

Ciel'om prieskumu bolo zistit' názory pedagógov a študentov na navrhnuté zmeny v príprave učitel'ov predmetu technika. V tejto súvislosti sme chceli zistit', či budú rozdiely vo vnímaní navrhovaných zmien medzi uvedenými skupinami respondentov. Predpokladali sme, že v odpovediach respondentov týchto dvoch skupín budú rozdiely. Tento predpoklad vychádzal $z$ toho, že študenti sú obvykle kritickejší voči náročnosti študijných programov ako aj k obsahom konkrétnych predmetov. Na zist'ovanie názorov respondentov sme zvolili formu neštandardizovaného dotazníka. Jednotlivé položky dotazníka sú distribuované do dvoch častí - dimenzií, ktoré zistovali názory respondentov na obsah študijného programu a jeho materiálno - technické zabezpečenie.

V rámci pilotného vyučovania, ktoré prebiehalo v akademickom roku 2014/15 boli v príprave učitel'ov predmetu technika využívané vo výučbe vybraných predmetov elektronické kurzy a nové učebné pomôcky. Po ukončení pilotného vyučovania bol študentom a pedagógom predložený dotazník na zistenie ich postojov a názorov na inovované študijné programy. Pri administrácii dotazníkov mali respondenti $\mathrm{k}$ dispozícii návrh nového študijného plánu a informačné listy predmetov. Celkový počet respondentov, ktorí vyplnili dotazník, bol 50, z toho 31 študentov a 19 pedagógov. Výsledky zistené dotazníkovou metódou sme spracovali metódami popisnej štatistiky a graficky. Na vyhodnotenie predpokladu o rozdiele v odpovediach respondentov podla ich rozdelenia na pedagógov a študentov sme použili dvojvýberový Wilcoxonov test. 
Použitie tohto testu vyplývalo predovšetkým z malých početností výberových súborov. Test vychádza z poradia údajov a zo skutočnosti, že väčšie namerané hodnoty majú vyššie poradie. Ak teda $\mathrm{v}$ jednej skupine máme viac väčších pozorovaní, priemerná hodnota poradí bude väčšia ako vdruhej skupine. Testovali sme hypotézu $\mathrm{H}_{0}$, že distribučné funkcie oboch rozdelení sú rovnaké. Test sme realizovali zvlášt' pre bakalársky stupeň štúdia a pre magisterský stupeň štúdia.

\section{Dotazník pre študentov zameraný na hodnotenie bakalárskeho študijného programu Učitel'stvo technickej výchovy}

Dotazník pre študentov na hodnotenie bakalárskeho stupňa študijného programu Učitel'stvo predmetu technika obsahoval 10 položiek. Vypíňali ho študenti posledného tretieho ročníka bakalárskeho štúdia v počte 19 respondentov. Dotazník obsahoval dve dimenzie - prvá dimenzia bola zameraná na hodnotenie obsahu študijného programu respondentmi a druhá dimenzia obsahovala ich vyjadrenia k materiálno - technickému zabezpečeniu študijného programu.

Položky 1 až 4 dotazníka boli formulované vo forme výrokov a respondenti sa mohli $\mathrm{k}$ uvedeným výrokom vyjadrovat' vo forme nasledovných postojov: úplne súhlasím, čiastočne súhlasím, neviem sa vyjadrit', čiastočne nesúhlasím, úplne nesúhlasím. Jednotlivým odpovediam boli priradené hodnoty $1-5$, pričom hodnotenie 1 zodpovedalo formulácii „úplne súhlasím“ a hodnotenie 5 formulácii „úplne nesúhlasím“. Položka 5 v dotazníku bola otvorená, aby mohli respondenti podrobnejšie opísat’ svoje názory $\mathrm{v}$ rámci jednotlivých dimenzií. Túto možnost' nikto nevyužil.

Položka 1: Predmety študijného plánu zodpovedajú profilu absolventa programu,

\section{ktorýs študujem.}

Študijný plán vzhl'adom na profil absolventa bol hodnotený kladnými postojmi, pričom 15 respondentov vyjadrilo úplný súhlas a štyria čiastočný súhlas s tvrdením. Priemerné ohodnotenie položky zodpovedá hodnote 1,21 .

Položka 2: Náročnost' odporúčaného študijného plánu (zaradenie jednotlivých predmetov do ročníkov a semestrov) považujem za primeranú.

$\mathrm{K}$ uvedenému tvrdeniu sa študenti vyjadrovali prostredníctvom kladných postojov, pričom desiati s tvrdením skôr súhlasili a deviati vyjadrili svoj jednoznačný súhlas. Priemerné ohodnotenie položky zodpovedá hodnote 1,53.

Položka 3: Ponuka povinne volitel'ných v programe a možnost' ich absolvovania je dostatočná.

Desiati študenti zaujali stanovisko s jednoznačných súhlasom, ôsmi sa vyjadrili $\mathrm{s}$ čiastočným súhlasom a jeden respondent sa nevedel vyjadrit'. Priemerné ohodnotenie položky zodpovedá hodnote 1,53 .

Položka 4: Ponuka volitel'ných predmetov v programe a možnost' ich absolvovania je dostatočná.

Ponuku volitel'ných predmetov $\mathrm{v}$ študijnom programe zhodnotilo postojom jednoznačne súhlasím až 15 študentov, pričom traja sa vyjadrili čiastočným súhlasom. Jeden respondent sa $\mathrm{k}$ ponuke volitel'ných predmetov nevedel vyjadrit'. Priemerné ohodnotenie položky zodpovedá hodnote 1,26.

Štruktúra bakalárskeho študijného programu Učitel'stvo predmetu technika bola hodnotená študentmi prevažne pozitívne. 
Postoje respondentov - študentov k informačným zdrojom a materiálno-technickému zabezpečeniu bakalárskeho štúdia:

Položka 1: Vzdelávacie priestory (jednotlivé učebne, prednáškové miestnosti a i.) sú primerané potrebám vyučovania.

Vzdelávacie priestory hodnotili respondenti ako vyhovujúce $\mathrm{v} 16$ prípadoch a $\mathrm{v}$ troch odpovediach ako čiastočne vyhovujúce. Priemerné ohodnotenie položky zodpovedá hodnote 1,16 .

Položka 2: Materiálno-technické zabezpečenie (pomôcky, didaktická technika a i.) pre potreby vyučovania je primerané.

Materiálno-technické zabezpečenie študijného programu technická výchova hodnotilo 16 študentov ako primerané a traja respondenti ako čiastočne primerané. Priemerné ohodnotenie položky zodpovedá hodnote 1,16.

Položka 3: Možnosti využ́vania IKT na podporu vzdelávania sú primerané.

15 študenti hodnotili možnosti využívania IKT na podporu vzdelávania ako primerané a štyria ich hodnotili ako čiastočne primerané. Priemerné ohodnotenie položky zodpovedá hodnote 1,21 .

Položka 4: Elektronické učebné materiály (elektronické učebnice, e-learningové kurzy a i.) pre potreby vyučovania sú primerané.

Pri štúdiu využívané elektronické učebné materiály a e-learningové kurzy zhodnotili študenti ako primerané $\mathrm{v} 11$ prípadoch a $\mathrm{v} 8$ prípadoch ako čiastočne primerané. Priemerné ohodnotenie položky zodpovedá hodnote 1,42.

Informačné zdroje a materiálno-technické zabezpečenie študijného programu Učitel'stvo predmetu technika boli hodnotené študentmi prevažne pozitívne. Ako vidíme $\mathrm{z}$ priemerných hodnôt jednotlivých položiek, žiadna $\mathrm{z}$ nich nepresiahla hodnotu 1,5 (graf 1), čo zodpovedá kladnému hodnoteniu.

5 Dotazník pre pedagógov zameraný na hodnotenie bakalárskeho študijného programu Učitel'stvo technickej výchovy

Dotazník na hodnotenie študijných programov vyplńali aj respondenti - učitelia študijného programu Učitelsstvo predmetu technika v počte 9.

Študijný plán vzhl'adom na profil absolventa bol hodnotený kladnými postojmi, pričom ôsmi respondenti vyjadrili úplný súhlas a jeden čiastočný súhlas $\mathrm{s}$ tvrdením (priemer 1,11). Náročnost' $\mathrm{k}$ odporúčaného študijnému plánu vyjadrovali respondenti prostredníctvom kladných postojov, pričom traja s tvrdením skôr súhlasili a šiesti vyjadrili svoj jednoznačný súhlas (priemer 1,33). Ôsmi pedagógovia zaujali jednoznačný súhlasom s ponúkanými povinne volitelnými predmetmi a jeden respondent vyjadril čiastočný súhlas (priemer 1,11).

Ponuku volitel'ných predmetov $\mathrm{v}$ študijnom programe zhodnotilo postojom jednoznačne súhlasím až 7 pedagógov, pričom jeden sa $\mathrm{k}$ uvedenému tvrdeniu nevedel vyjadrit' (priemer 1,25). Jeden respondent $\mathrm{v}$ tejto položke neuviedol žiadnu odpoved'.

Štruktúra bakalárskeho študijného programu Učitel'stvo predmetu technika bola hodnotená pedagógmi prevažne pozitívne.

Postoje respondentov - pedagógov $\mathrm{k}$ informačným zdrojom a materiálnotechnickému zabezpečeniu bakalárskeho štúdia: 
Vzdelávacie priestory hodnotili respondenti ako vyhovujúce $\mathrm{v}$ dvoch prípadoch a v siedmich odpovediach sme zaznamenali postoj respondentov vyjadrujúci čiastočnú spokojnost' (priemer 1,77). Materiálno-technické zabezpečenie študijného programu Učitel'stvo predmetu technika hodnotil jeden pedagóg ako primerané, siedmi respondenti ako čiastočne primerané a jeden vyjadril svoj postoj čiastočným nesúhlasom (priemer 2,11). Traja pedagógovia hodnotili možnosti využívania IKT na podporu vzdelávania ako primerané, štyria ako čiastočne primerané a jeden hodnotil tento atribút čiastočným nesúhlasom (priemer 1,88). Pri štúdiu využivané elektronické učebné materiály a e-learningové kurzy zhodnotili ako primerané traja pedagógovia, štyria ich zhodnotili ako čiastočne primerané a jeden ako skôr neprimerané (priemer 1,88). Jeden respondent sa $\mathrm{k}$ tretej a štvrtej položke vôbec nevyjadril.

Informačné zdroje a materiálno-technické zabezpečenie študijného programu Učitel'stvo predmetu technika boli hodnotené pedagógmi prevažne pozitívne. Z priemerných hodnôt jednotlivých položiek môžeme vidiet', že pedagógovia boli v hodnotení materiálno - technického zabezpečenia predmetu ovela kritickejší ako študenti (graf 1$)$.

\section{Dotazník pre študentov zameraný na hodnotenie magisterského študijného programu Učitel'stvo technickej výchovy}

Počet respondentov, ktorí vyplnili dotazník bolo 12. Študijný plán vzhl’adom na profil absolventa bol hodnotený kladnými postojmi, pričom piati respondenti vyjadrili úplný súhlas a siedmi čiastočný súhlas $\mathrm{s}$ tvrdením (priemer 1,58). Náročnost' odporúčaného študijného plánu hodnotili štyria študenti jednoznačne pozitívne a ôsmi s tvrdením skôr súhlasili (priemer 1,66). Jednoznačne kladne bola hodnotená ponuka povinne volitel'ných predmetov ôsmimi študentmi a štyria študenti ju považujú za vyhovujúcu s výhradami (priemer 1,33). Ponuku volitel’ných predmetov v študijnom programe zhodnotilo postojom jednoznačne súhlasím šest’ študentov a štyria vyjadrili čiastočný súhlas (priemer 1,4). Dvaja respondenti sa $\mathrm{k}$ danej položke nevyjadrili.

Štruktúra magisterského študijného programu Učitel'stvo predmetu technika bola hodnotená študentmi prevažne pozitívne. Postoje respondentov - študentov k informačným zdrojom a materiálno-technickému zabezpečeniu magisterského štúdia:

Vzdelávacie priestory hodnotili respondenti ako vyhovujúce $\mathrm{v}$ siedmich prípadoch a $\mathrm{v}$ troch odpovediach sme zaznamenali čiastočnú spokojnost' respondentov (priemer 1,3). Materiálno-technické zabezpečenie študijného programu Učitel'stvo predmetu technika hodnotili štyria študenti ako primerané a šiesti respondenti ako čiastočne primerané (priemer 1,6). Štyria študenti zhodnotili možnosti využívania IKT na podporu vzdelávania ako primerané a šiesti hodnotili tieto možnosti ako čiastočne primerané (priemer 1,6). Pri štúdiu využívané elektronické učebné materiály a e-learningové kurzy zhodnotili ako primerané siedmi študenti a traja ich zhodnotili ako čiastočne primerané (priemer 1,3 ). Dvaja respondenti sa k položkám druhej dimenzie nevyjadrili.

Informačné zdroje a materiálno-technické zabezpečenie študijného programu Učitel'stvo predmetu technika boli hodnotené študentmi prevažne pozitívne. Najhoršie bola hodnotená položka týkajúca sa náročnosti magisterského študijného programu, 
kde priemer položky dosiahol hodnotu 1,66 . Všetky ostatné položky boli v priemere hodnotené nižšími hodnotami, teda študijný program podl'a hodnotenia študentov je navrhnutý dobre.

\section{Dotazník pre pedagógov zameraný na hodnotenie magisterského študijného programu Učitel'stvo technickej výchovy}

Počet respondentov, ktorí vyplnili všetky položky dotazníka bol 10. Študijný plán vzhl’adom na profil absolventa bol hodnotený kladnými postojmi, pričom deviati respondenti vyjadrili úplný súhlas a jeden sa $\mathrm{k}$ uvedenému nevedel vyjadrit' (priemer 1,2). Náročnost' odporúčaného študijného plánu hodnotili pedagógovia prevažne prostredníctvom kladných vyjadrení, pričom dvaja s tvrdením skôr súhlasili a siedmi vyjadrili svoj jednoznačný súhlas a jeden sa $\mathrm{k}$ uvedenému nevedel vyslovit' (priemer 1,4). Deviati pedagógovia vyjadrili jednoznačný súhlas $s$ ponukou povinne volitel'ných predmetov a jeden sa $\mathrm{k}$ uvedenému atribútu nevedel vyjadrit' (priemer 1,2). Ponuku volitel'ných predmetov $\mathrm{v}$ študijnom programe zhodnotilo postojom jednoznačne súhlasím až sedem pedagógov, pričom dvaja sa $\mathrm{k}$ uvedenému tvrdeniu nevedeli vyjadrit' (priemer 1,44). Jeden respondent sa $\mathrm{k}$ danej položke nevyjadril.

Štruktúra magisterského študijného programu Učitel'stvo predmetu technika bola hodnotená pedagógmi prevažne pozitívne. Študijný plán pre magisterské štúdium bol aj pedagógmi hodnotený kladne, prevažovali kladné vyjadrenia respondentov.

Hodnotenie informačných zdrojov a materiálno-technického zabezpečenia študijného programu:

Vzdelávacie priestory hodnotili respondenti ako vyhovujúce $\mathrm{v}$ deviatich prípadoch a $\mathrm{v}$ jednej odpovedi sme zaznamenali postoj respondenta $\mathrm{s}$ čiastočnou spokojnost'ou (priemer 1,1). Materiálno-technické zabezpečenie študijného programu Učitel'stvo predmetu technika hodnotilo šest' pedagógov ako primerané, jeden respondent ho hodnotil ako čiastočne primerané a jeden vyjadril svoj postoj čiastočným nesúhlasom (priemer 1,8). Dvaja respondenti sa $\mathrm{k}$ položke nevedeli vyjadrit'. Jeden pedagóg zhodnotil možnosti využívania IKT na podporu vzdelávania ako primerané, siedmi hodnotili ich využívanie ako čiastočne primerané a dvaja sa nevedeli vyjadrit' (priemer 2,1). Pri štúdiu využívané elektronické učebné materiály a e-learningové kurzy zhodnotili ako primerané štyria pedagógovia, dvaja ich zhodnotili ako čiastočne primerané a štyria sa nevedeli k uvedenému vyjadrit' (priemer 2,1).

Informačné zdroje a materiálno-technické zabezpečenie študijného programu Učitel'stvo predmetu technika boli hodnotené pedagógmi prevažne pozitívne. Z priemerného ohodnotenia odpovedí respondentov vidiet', že pedagógovia sa kriticky vyjadrovali najmä $\mathrm{k}$ možnostiam využívania IKT študentmi a $\mathrm{k}$ úrovni elektronických študijných materiálov. Môže íst' o pedagógov, ktorí sami nevytvorili e-learningové kurzy a tiež nevyužívajú iné elektronické kurzy na výučbu a preto ich subjektívne odpovede sú týmto zatažené.

$\mathrm{V}$ d’alšom sme sa zaoberali porovnaním odpovedí respondentov $\mathrm{z}$ hl'adiska ich rozdelenia na študentov a pedagógov. Ako sme už v úvode uviedli, predpokladali sme, že študenti budú v odpovediach kritickejší ako pedagógovia. Tento predpoklad sme overovali pre každý študijný program (bakalársky, magisterský) zvlášt'. 
Testujeme priemerné hodnoty dosiahnuté $\mathrm{v}$ jednotlivých položkách v dotazníkovom prieskume zameranom na bakalárske štúdium. Uvedené hodnoty sú realizáciami dvoch nezávislých náhodných výberov z dvoch spojitých rozdelení. Budeme testovat' hypotézu $\mathrm{H}_{0}$, že distribučné funkcie oboch rozdelení sú rovnaké pomocou dvojvýberového Wilcoxonovho testu oproti alternatívnej hypotéze $\mathrm{H}_{\mathrm{Ab}}$, že distribučné funkcie oboch rozdelení sú rôzne.

Hodnota testovacieho kritéria $\mathrm{U}_{0}=\min \left(\mathrm{U}_{1}, \mathrm{U}_{2}\right)=23$. Tabul'ková hodnota pre $\mathrm{m}=8$, $\mathrm{n}=8$ na hladine významnosti $\alpha=0,05$ je 7 . Ked’že pre hodnotu testovacieho kritéria $\mathrm{U}_{0}$ neplatí, že $\mathrm{U}_{0}<7$, testovanú hypotézu $\mathrm{H}_{0}$ nemôžeme zamietnut'. To znamená, že v odpovediach študentov a pedagógov nie je štatisticky významný rozdiel v názoroch na bakalárske štúdium učitel'stva predmetu technika.

Testujeme priemerné hodnoty dosiahnuté $\mathrm{v}$ jednotlivých položkách v dotazníkovom prieskume zameranom na magisterské štúdium. Budeme testovat' hypotézu $\mathrm{H}_{0}$, že distribučné funkcie oboch rozdelení sú rovnaké pomocou dvojvýberového Wilcoxonovho testu. Alternatívna hypotéza $\mathrm{H}_{\mathrm{Am}}$ znie: Distribučné funkcie oboch rozdelení sú rôzne. Hodnota testovacieho kritéria $U_{0}=\min \left(U_{1}, U_{2}\right)=31,5$. Tabul'ková hodnota pre $\mathrm{m}=8, \mathrm{n}=8$ na hladine významnosti $\alpha=0,05$ je 7 . Nakol'ko pre vypočítanú hodnotu testovacieho kritéria $\mathrm{U}_{0}$ neplatí, že $\mathrm{U}_{0}<7$, testovanú hypotézu $\mathrm{H}_{0}$ nemôžeme zamietnut'. To znamená, že $\mathrm{v}$ odpovediach študentov a pedagógov nie je štatisticky významný rozdiel v názoroch na magisterské štúdium učitel'stva predmetu technika.

Zo štatistického skúmania vyplýva, že oba stupne študijného programu boli hodnotené kladne a $\mathrm{v}$ odpovediach študentov a pedagógov nebol zistený štatisticky významný rozdiel na hladine významnosti $\alpha=0,05$.

\section{Diskusia výsledkov}

Výsledky získané $\mathrm{z}$ nášho prieskumu sumarizujeme $\mathrm{v}$ grafe 1a 2 podl’a priemerných hodnôt odpovedí na jednotlivé položky v oboch dimenziách a podl’a daného študijného programu. Položky prvej dimenzie sú označené arabskými číslicami a položky druhej dimenzie sú v grafe označené rímskymi číslicami.

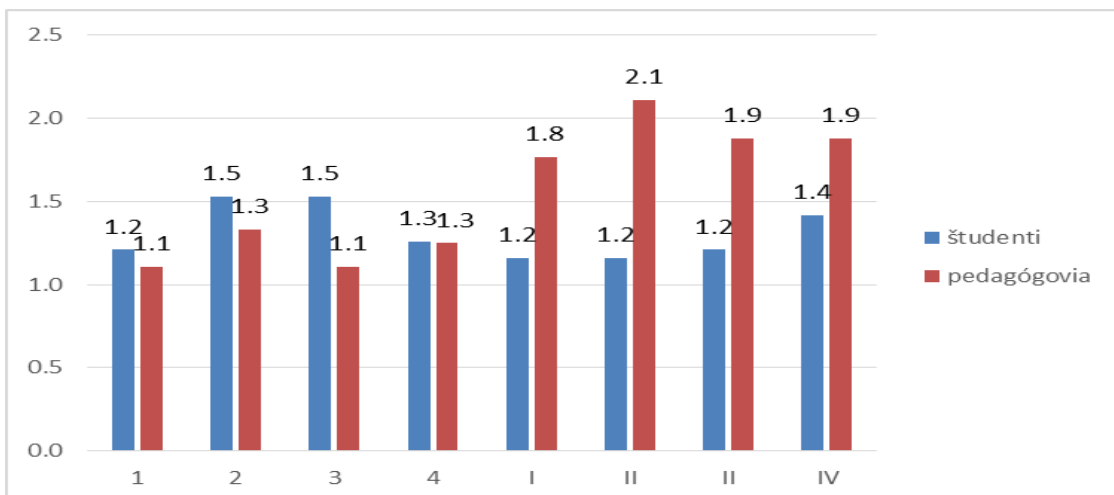

Graf 1 Priemerné hodnoty z odpovedi na dotazník bakalárskeho študijného programu. 
Ako vyplýva z uvedených hodnôt zobrazených na grafe 1 a na základe výsledkov $\mathrm{z}$ testovania hypotézy $\mathrm{H}_{\mathrm{Ab}}$, môžeme konštatovat', že sme $\mathrm{v}$ názoroch hodnotenia bakalárskeho študijného programu zaznamenali rozdielne hodnotenia od študentov a pedagógov (aj ked' nie štatisticky významné). V prvej dimenzii orientovanej na hodnotenie obsahu študijného programu vyjadrili pozitívnejší postoj pedagógovia na rozdiel od študentov. V druhej dimenzii, ktorá sa orientovala na materiálno - technické zabezpečenie študijného programu vyjadrili pozitívnejší postoj študenti. Toto zistenie môžeme považovat' za prekvapivé, nakol'ko všeobecne názory študentov bývajú na túto oblast' kritickejšie. Pedagógovia, ktorí prakticky majú možnost' do určitej miery ovplyvnit' materiálno-technické vybavenie pracoviska na ktorom pôsobia, ho hodnotili kritickejšie. Tento ich postoj vznikol na základe ich skúseností. Teda existuje rozdiel u pedagógov vo vnímaní svojho pracoviska a možnostami jeho technického vybavenia. Praktické skúsenosti sa v tomto prípade odrazili v negatívnejšom hodnotení daného študijného programu. Na túto skutočnost' poukazuje napríklad aj Akili (2015), ked’ uvádza, že fakulty by mohli obohatit’ akademický program tým, že do študijných programov zaradia praktické skúsenosti a príslušné aplikácie (pomôcky). Praktické skúsenosti približujú študentov bližšie k realite na pracovisku.

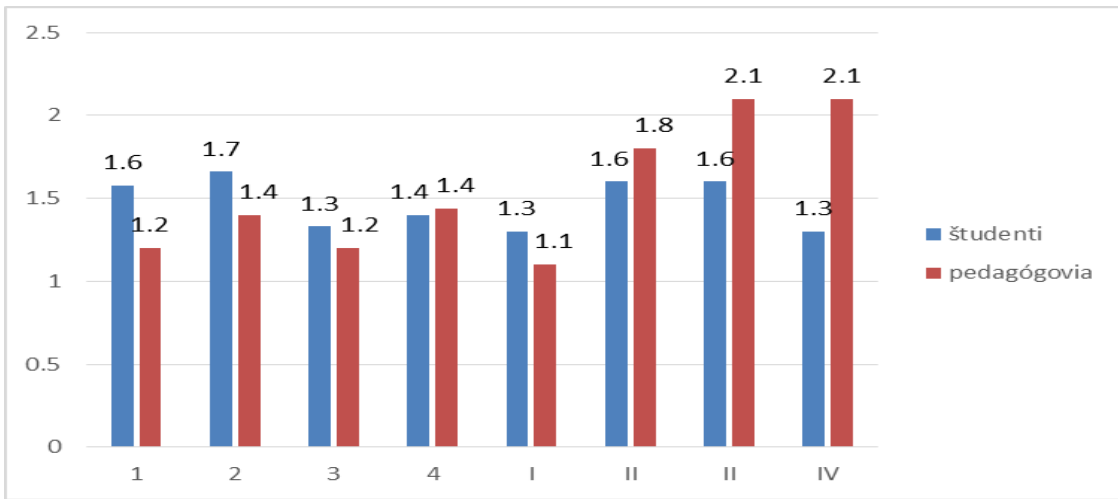

Graf 2 Priemerné hodnoty z odpovedí na dotazník magisterského študijného programu.

Z grafu 2 a výsledkov testovania hypotézy $\mathrm{H}_{\text {Am, }}$, môžeme konštatovat', že v hodnotení výsledkov z dotazníkov na magisterský študijný program zaznamenali porovnatel'né hodnotenia od študentov a pedagógov.

V tomto prípade môžeme vziat' do úvahy, tú skutočnost', že ak študenti kritickejšie hodnotili daný študijný program, tak ich skúsenosti so štúdiom na vysokej škole sú už dané minimálne trojročným štúdiom v rámci bakalárskeho stupňa. $Z$ tohto pohladu by tento študijný program, určený pre druhý stupeň vysokoškolského štúdia, mal byt' orientovaný viac na praktické predmety. Na túto skutočnost' vo svojom výskume upozorňuje rovnako aj Akili, ked’ uvádza: Doplnenie pravidelných prednášok 
ponúkaných v 4. ročníku inžinierskeho štúdia praktickými prednáškami, exkurziami a praktickými činnost’ami hodnotili študenti prinajmenšom povzbudivo. (Akili, 2015).

Sme toho názoru, že technické zabezpečenie inovovaných predmetov magisterského štúdia študijného programu Učitel'stvo predmetu technika bolo jednoznačne skvalitnené.

\section{Záver}

Univerzity majú v novej, znalostnej ekonomike dôležité postavenie - sú zdrojom znalostí a inovácií a sú $\mathrm{v}$ centre inovačných procesov. Inovácie pomáhajú zvyšovat' konkurencieschopnost' $\mathrm{v}$ globálnom ekonomickom prostredí a ich zavádzanie do výrobných procesov a služieb v podobe nových technológií, znalostí a skúseností pracovnej sily zvyšuje pridanú hodnotu tovarov a služieb. (Černá, 2007, s. 91) Tovarom univerzít by sme mohli nazvat' študijné programy, ktoré univerzity ponúkajú záujemcom o štúdium. Kvalitný študijný program je hlavným produktom univerzity ako vzdelávacej inštitúcie, od ktorého sa odvíja jej úspešnost', ohlas a pozícia na trhu vzdelávania, a preto by sa jeho zdokonal'ovaniu mala venovat' trvalá pozornost'. Je to produkt, ktorý poskytuje úžitok, má kvalitu a cenu, na jeho tvorbu a prevádzku boli a sú vynakladané náklady. Zavádza sa do vyučovania, používa sa, inovuje sa a vyrad’uje sa z používania. Inovácii podliehajú aj spôsoby jeho používania (vyučovania). Produkt by mal byt' ponúkaný so správnymi parametrami, v správnom čase a s vhodnými sprievodnými službami. Vnímanie vzdelávacieho produktu je však dost' individuálne. Niekto očakáva od vzdelania jednoznačný prínos v získaní atraktívnejšieho zamestnania a pracovného miesta, iný si chce všeobecnejšie rozšírit' vzdelanostný obzor, d'alšiemu ide len o získanie diplomu. (Slávik, 2007) Tieto očakávania sa odrazili aj v odpovediach študentov, ktorých sme oslovili pri hodnotení inovovaných študijných programov. Napriek týmto rozličným očakávaniam boli odpovede študentov priaznivé - prevažne kladnými odpoved’ami hodnotili oba stupne inovovaného študijného programu. Náš predpoklad, že budú kritickejší ako pedagógovia vo svojich odpovediach sa nepotvrdil. Prieskum postojov študentov a pedagógov $\mathrm{k}$ inovovaným študijným programom preukázal, že náročnost' zostavených študijných programov je primeraná, ponuka povinne volitel'ných a volitel'ných predmetov tiež. Materiálne zabezpečenie študijných programov pre Učitel'stvo predmetu technika bolo hodnotené ako vyhovujúce, najviac pripomienok bolo zaznamenaných zo strany pedagógov $\mathrm{k}$ dostupnosti IKT a e learningových kurzov pre študentov. V budúcnosti je preto potrebné plánovat' rozšírenie materiálno - technického vybavenia pracoviska pre výučbu technických predmetov ako aj doplnenie elektronických študijných materiálov pre študentov.

\section{Literatúra}

Akili, W. (2015) On the Role of Adjuncts in Engineering Education: Developing Practical Courses and Solving Real World Problems. In 122nd ASEE Annual Conference\& Exposition. Paper presented at 2015 ASEE Annual Conference and Exposition, Seattle, Washington. 10.18260/p.24536

Bajtoš, J. \& Šnajder, L. \& Orosová, R. \& Kireš, M. (2009) Čiastkové výsledky výskumu úrovne psychodidaktických kompetencií učitel'ov. In Media4u Magazine, mimoriadne vydanie. Modernizace vysokoškolské výuky technických předmětů. Hradec Králové, PdF [online]. Dostupné na: http://www.media4u.cz/mvvtp2009.pdf. 
Černá, J. (2009) Úlohy univerzít v dynamike znalostných procesov. In Region Direct. Banská Bystrica: REIC, s. 80 - 106.

Chaschin, V. V. (2014) Actual Problems of Development of the System of Higher Education of the Russian Federation: The Institutional Aspects. In Asian Social Science; Vol. 10, No. 23; Published by Canadian Center of Science and Education.

Lukáčová, D. (2014) Požiadavky stredných odborných škôl na absolventov. In Edukacja - Technika-Informatyka. Rzeszów: Fosze, roč. 5, č. 1, s. 45-50.

Nezamestnanost’ absolventov škôl a jej riešenie $v$ členských štátoch EU v období globálnej ekonomickej krízy. Záverečná správa. (2010).Výskumná úloha VÚ 2146 [online]. Bratislava: Inštitút pre výskum práce a rodiny, Dostupné $\mathrm{z}$ WWW: http://www.sspr.gov.sk/IVPR/images/IVPR/vyskum/2010/Kostolna/VU_2146_Kostolna. pdf.

Potocký, R. a kol. (1991). Zbierka úloh z pravdepodobnosti a matematickej štatistiky. Bratislava: Alfa.

Rybalko, Y. \& Epelboim, O. (2014) Quality Control of Education in the Universities of Ukraine. In Technika a vzdelávanie. Banská Bystrica: UMB, roč. 3, č. 2, s. 456 - 459. Slávik, Š. (2007) Determinanty tvorby študijných programov v študijných odboroch Manažment a Ekonomika a manažment podniku [online]. Dostupné z WWW: http://semafor.euke.sk/zbornik2007/pdf/slavik2.pdf. 